\title{
Effect of ocean acidification on growth, gonad development and physiology of the sea urchin Hemicentrotus pulcherrimus
}

\author{
Haruko Kurihara ${ }^{1, *}$, Rui Yin ${ }^{2}$, Gregory N. Nishihara ${ }^{2}$, Kiyoshi Soyano ${ }^{2}$, \\ Atsushi Ishimatsu ${ }^{2}$ \\ ${ }^{1}$ Transdisciplinary Research Organization for Subtropical Island Studies, University of the Ryukyus, 1 Senbaru, Nishihara, \\ Okinawa 903-0213, Japan \\ ${ }^{2}$ Institute for East China Sea Research, Nagasaki University, 1551-7 Taira-machi, Nagasaki 851-2213, Japan
}

\begin{abstract}
Ocean acidification, due to diffusive uptake of atmospheric $\mathrm{CO}_{2}$, has potentially profound ramifications for the entire marine ecosystem. Scientific knowledge on the biological impacts of ocean acidification is rapidly accumulating; however, data are still scarce on whether and how ocean acidification affects the reproductive system of marine organisms. We evaluated the long-term $(9 \mathrm{mo})$ effects of high $\mathrm{CO}_{2}(1000 \mu \mathrm{atm})$ on the gametogenesis, survival, growth and physiology of the sea urchin Hemicentrotus pulcherrimus. Hypercapnic exposure delayed gonad maturation and spawning by 1 mo, whereas it had no effect on the maximum number of ova, survival or growth. After 9 mo of exposure, $\mathrm{pH}$ (control: 7.61, high- $\mathrm{CO}_{2}: 7.03$ ) and $\mathrm{Mg}^{2+}$ concentration (control: 50.3, high- $\mathrm{CO}_{2}: 48.6 \mathrm{mmol} \mathrm{l}^{-1}$ ) of the coelomic fluid were significantly lower in the experimental urchins. In addition, a $16 \mathrm{~d}$ exposure experiment revealed that $1000 \mu \mathrm{atm} \mathrm{CO}_{2}$ suppressed food intake to $<30 \%$ of that of the controls. These data suggest that the ocean condition predicted to occur by the end of this century disrupts the physiological status of the sea urchin, possibly through reduced energy intake, which may delay reproductive phenology of the species. Taking into account earlier studies reporting negative impacts of ocean acidification on the early development of the same species, these results imply that ocean acidification will threaten $H$. pulcherrimus at a community level.
\end{abstract}

KEY WORDS: $\mathrm{CO}_{2} \cdot$ Ocean acidification $\cdot$ Sea urchin $\cdot$ Reproduction $\cdot$ Feeding $\cdot$ Physiology

\section{INTRODUCTION}

There is wide recognition that the increasing concentration of atmospheric $\mathrm{CO}_{2}$ is acidifying oceans through diffusional entry of the gas into surface seawater (termed ocean acidification; Caldeira \& Wickett 2003, IPCC 2007). Increasing acidity of seawater shifts carbonate equilibria so that carbonate ions bind to $\mathrm{H}^{+}$ions to form bicarbonate ions, thereby reducing the $\mathrm{CaCO}_{3}$ saturation state of seawater (Orr et al. 2005). Not surprisingly, most ocean acidification studies have used dominant marine calcifiers, e.g. coccolithophores, corals, mollusks and foramini- ferans, and revealed reductions in calcification rates (Riebesell et al. 2000, Kleypas et al. 2006, Gazeau et al. 2007, Hofmann et al. 2010), but there are notable exceptions to this general finding (Ries et al. 2009, Kroeker et al. 2010). Meanwhile, more recent studies have demonstrated a much wider spectrum of biological consequences invoked by ocean acidification, which includes immune responses, growth, physiology and behavior (Bibby et al. 2008, Kurihara et al. 2008, Melzner et al. 2009, Domenici et al. 2012).

Given that living in a high $\mathrm{CO}_{2}$, acidified environment constitutes stress to marine inhabitants, increasing $\mathrm{CO}_{2}$ could have profound ramifications on 
the biological process by affecting the energy balance of the organism. The energy budget of living organisms follows the 'law of conservation of energy', and the energy input (food source) is equal to the energy output, which is divided between growth (production of tissue), reproduction (production of gametes), maintenance metabolism and excretory loss (Sibly \& Calow 1986). Under low energy input or stress conditions, this allocation is suggested to follow the principles of maximizing fitness, and studies have shown that allocation to maintenance tends to take precedence over growth or reproduction (Zera \& Harshman 2001, Schneider 2004, Koojiman 2010, Sokolova et al. 2012). Recent studies have indicated that an acidified environment involves potential energy costs for metabolic adaptations and calcification (Melzner et al. 2009, Lannig et al. 2010, Sokolova et al. 2012, Stumpp et al. 2012), thus one might expect that reallocation of energy between somatic and gonad growth will occur in acidified conditions. However, though there are several studies evaluating the effect of ocean acidification on growth rate, to our knowledge, there is a limited number of studies that have examined the effect of high $\mathrm{CO}_{2}$ on the reproductive potential of marine organisms. Wood et al. (2008) reported that egg size was not affected in regenerating arms of ophiuroid Amphiura filiformis cultured in seawater $\mathrm{pH} 7.7,7.3$ and 6.8 for $40 \mathrm{~d}$. Exposure of adult copepods (Acartia steueri and A. tsuenis) to high $\mathrm{CO}_{2}(2000 \mu \mathrm{atm})$ also did not affect their egg production (Kurihara et al. 2004, Kurihara \& Ishimatsu 2008). However, Fitzer et al. (2012) recently demonstrated that the body length of the copepod Tisbe battagliai decrease at $\mathrm{pH}$ 7.67, while the naupliar production was significantly higher at pH 7.67 compared with $\mathrm{pH} 7.82$, and the authors suggested that copepods preferentially reallocate resources to maintain reproduction at the expense of somatic growth during the maturation stage. Gonad dry mass and growth of the sea urchin Strongylocentrotus drobachiencis reared under $1007-$ 1431 and $2800-3800 \mu a t m \mathrm{pCO}_{2}$ for $45 \mathrm{~d}$ was found to be significantly affected, while ammonium excretion increased (Stumpp et al. 2012). These studies suggest that allocation of energy under stress conditions may differ between species, and evaluation of the responses of different traits, including energy intake, metabolism, somatic and gonad growth, is fundamental for better understanding the energetic strategy of the organism under acidified stress conditions.

In the present study, adult sea urchins Hemicentrotus pulcherrimus were reared for 9 mo under control (atmospheric $\mathrm{CO}_{2}$ concentration $380 \mu$ atm and high-
$\mathrm{CO}_{2}(1000 \mu \mathrm{atm})$ conditions to evaluate the effects of hypercapnia on survival, somatic growth, gonad index, gametogenesis cycle, egg production and several physiological parameters, including oxygen uptake rate, $\mathrm{pH}$, and $\mathrm{Ca}^{2+}$ and $\mathrm{Mg}^{2+}$ ion concentrations of the coelomic fluid. Additionally, a short-term (16 d) experiment was conducted to evaluate the effects of $1000 \mu$ atm $\mathrm{CO}_{2}$ on feeding rate. The $\mathrm{CO}_{2}$ condition was adopted in accordance with the A1FI emission scenario (atmospheric $\mathrm{CO}_{2}$ concentration 825 to $1250 \mu$ atm by the year 2100; IPCC 2007).

\section{MATERIALS AND METHODS}

\section{Origin of animals}

Adult sea urchins Hemicentrotus pulcherrimus (test diameter 30-40 mm) were collected in September 2007 (long-term experiment) and October 2008 (short-term experiment) from a subtidal rocky shore ( $<1 \mathrm{~m}$ depth) near the Asamushi Marine Biological Station, Tohoku University in Sendai, Japan, and transported to Institute for East China Sea Research (ECSER), Nagasaki University, where the experiments were conducted. $H$. pulcherrimus spawns in December through April and is in spent stage during June to November along the Japanese coasts (Fuji 1960). All sea urchins were reared in a 3 stock aquaria (capacity $45 \mathrm{l}$ ) for more than $1 \mathrm{mo}$; the aquaria were provided with running seawater $\left(100 \mathrm{ml} \mathrm{min}^{-1}\right)$ to allow recovery from the transportation before the experiments began. During acclimation, the sea urchins were fed on the sea alga Undaria pinnatifida every other day.

\section{Long-term $\mathrm{CO}_{2}$ exposure}

Experimental system

Following acclimation, sea urchins were reared in 2 sets of recirculating systems (flow rate $101 \mathrm{~min}^{-1}$ ), each consisting of an aquarium (capacity $45 \mathrm{l}$ ) and a header tank (capacity 72 l). Natural seawater was pumped from $20 \mathrm{~m}$ depth from the coast in front of ECSER, filtered, and continually supplied to each header tank at a rate of $100 \mathrm{ml} \mathrm{min}^{-1}$. Seawater in the header tank of the control and experimental setups was bubbled at a rate of $10 \mathrm{l} \mathrm{min}^{-1}$ with outdoor air and with $\mathrm{CO}_{2}$-enriched air containing 1000 patm $\mathrm{CO}_{2}$ supplied by a mass-flow controller (SECE50MK3 for air, and SEC-E40 for $\mathrm{CO}_{2}$ HORIBA 
STEC), respectively. The light regime was controlled with a time switch (Hitachi AW-700), where the cycle was adjusted every 2 wk to simulate the natural photoperiod. Seawater salinity, pH (NBS scale) and temperature of the aquaria were measured daily with a refractometer (Atago 100-S), a pH meter (Mettler Toledo MP125) and a thermometer (SS SATO, SK$1250 \mathrm{MCIII} \alpha)$, respectively. Seawater alkalinity was determined with a PHM290 $\mathrm{pH}$ meter and an ABU901 autoburette (Radiometer). Seawater carbonate chemistry was calculated using CO2SYS (Lewis \& Wallace 1998).

Two hundred specimens were chosen randomly from the stock, divided into 2 groups of 100 individuals of similar size and reared for 9 mo (the initial mean test diameters \pm SD of the control and high$\mathrm{CO}_{2}$ groups were $35.7 \pm 3.1$ and $35.2 \pm 3.0 \mathrm{~mm}$, respectively). The experiment was conducted from October 2007 to June 2008 so that the sea urchins were exposed to experimental conditions through all gametogenesis cycles (from the spent stage in 2007 until the next spent stage in 2008). The sea urchins were fed on $1 \mathrm{~g}$ sea algae Undaria pinnatifida per individual every other day. Feces were removed from the aquaria $1 \mathrm{~d}$ after feeding.

\section{Growth rate and gonad development}

Dead animals were counted every day and removed from the aquarium. Size (test diameter) and wet weight of all sea urchins were measured monthly. The size was determined with calipers to the nearest $0.1 \mathrm{~mm}$ and was standardized using the initial mean value of each group determined in October 2007. The wet weight was measured to the nearest $0.01 \mathrm{~g}$ after blotting the sea urchins. Each month, 10 sea urchins were sampled randomly from each aquarium and dissected into test, masticating apparatus (Aristotle's lantern), gonad and the rest of the soft body. Hence, numbers of sea urchins in each aquarium decreased with time. Wet weights of the whole body, calcium carbonate test and Aristotle's lantern, and gonad of these animals were measured to the nearest $0.01 \mathrm{~g}$. The soft-body wet weight and gonad index (GI) were calculated as soft-body wet weight $=$ whole-body wet weight - (test + Aristotle's lantern + gonad wet weights), and GI $(\%)=$ (gonad wet weight) (whole-body wet weight) ${ }^{-1} \times 100$ ), respectively. After the measurements, one of the 5 gonads per individual was fixed in Bouin's solution for histological determination of maturation stages and quantification of ova in cross-sections of the ovary. Paraf- fin sections $5 \mu \mathrm{m}$ thick were prepared using an RM2135 microtome (Leica Microsystems) and stained with hematoxylin and eosin. Stages of the gametogenesis cycle of both males and females were judged according to Fuji (1960): stage I (spent recovering stage); stage II (growing stage); stage III (premature stage); stage IV (mature stage); and stage V (spent stage). The number of ova (mature eggs) was counted for all sampled females in February and March, when most individuals were at either the premature or mature stage. In January, April, May and June, counts were done for 3 females only. Each gonad was cut into 3 parts of approximately the same length along the longitudinal axis and the number of ova was counted in the cross-sections of 7 to 11 discontiguous slides from the second, central part of the ovary.

\section{Respiration rate}

At the end of the long-term experiment, the respiration rate of each of 13 individuals reared for 9 mo under control or high- $\mathrm{CO}_{2}$ seawater was measured using a closed respirometric chamber $(240 \mathrm{ml})$. A sea urchin was transferred individually into the chamber continuously supplied with control or high- $\mathrm{CO}_{2}$ seawater and habituated to the condition for $24 \mathrm{~h}$. After the acclimation, the seawater flow was stopped, and $0.5 \mathrm{ml}$ seawater samples were taken at Time 0,30 and $60 \mathrm{~min}$ for the determination of dissolved oxygen concentration. Seawater in the chamber was continuously mixed with a magnetic stirrer and seawater temperature was kept at $22^{\circ} \mathrm{C}$. The oxygen concentration of the seawater samples was measured using an oxygen electrode (Model 1302, Strathkelvin) connected to an oxygen meter (Model 782, Strathkelvin). Preliminary determinations without sea urchins verified negligible bacterial oxygen consumption. The oxygen saturation remained above $85 \%$ throughout the measurements. After the measurements, body wet weight was determined as described above.

\section{$\mathrm{pH}$ and ion concentration}

To evaluate coelomic fluid $\mathrm{pH},\left[\mathrm{Ca}^{2+}\right]$ and $\left[\mathrm{Mg}^{2+}\right]$ of sea urchins after 9 mo exposure, $1.0 \mathrm{ml}$ perivisceral coelomic fluid was sampled by puncturing the peristominal membrane with a syringe. The $\mathrm{pH}$ of the $500 \mu \mathrm{l}$ perivisceral fluid was immediately measured after sampling using a micro $\mathrm{pH}$ electrode (Mettler Toledo, InLab Micro). The rest of the sample was 
frozen for later analyses of $\left[\mathrm{Ca}^{2+}\right]$ and $\left[\mathrm{Mg}^{2+}\right]$. Prior to ion determinations, $500 \mu \mathrm{l}$ of perivisceral fluid samples were diluted in $100 \mathrm{ml}$ milli-Q water and $\left[\mathrm{Ca}^{2+}\right]$ and $\left[\mathrm{Mg}^{2+}\right]$ were measured using the ICP-AES (ULTIMA2, HORIBA).

\section{Short-term exposure experiment}

To evaluate the effect of ocean acidification on the feeding rate of individual sea urchins, an additional short-term experiment was conducted. A total of 20 sea urchins (mean \pm SD wet weight $21 \pm 4.9 \mathrm{~g}$ ) were kept individually in mesh $(80 \mu \mathrm{m})$-covered plastic chambers (capacity $500 \mathrm{ml}$ ) placed in 2 aquaria (10 chambers per aquaria). Each chamber was continuously supplied with well-aerated, temperature-controlled $\left(18^{\circ} \mathrm{C}\right)$ seawater from one of 2 header tanks. Seawater overflowed from the top of the chambers to the aquaria, and was recirculated to the header tanks. An additional heater was placed in each aquarium. After a week of acclimation, the seawater $\mathrm{CO}_{2}$ condition in each of the 2 header tanks was adjusted to either $380 \mu \mathrm{atm} \mathrm{CO}_{2}$ (control) or $1000 \mu \mathrm{atm} \mathrm{CO}_{2}$ (high- $\mathrm{CO}_{2}$ ). Temperature and $\mathrm{pH}$ were checked daily for aquarium seawater. Feeding rates were determined for all individuals as follows. During the $16 \mathrm{~d}$ period (5 to 21 January 2009), the sea urchins were fed with a known weight of Undaria pinnatifida every other day. The alga was first dried at $60^{\circ} \mathrm{C}$ for $24 \mathrm{~h}$, and measured to the nearest $0.001 \mathrm{~g}$ before being given to the animals. Residual food was collected on the following day, dried and weighed in the same manner to evaluate the food intake after correcting for dissolution of the food in seawater in $24 \mathrm{~h}$ without a sea urchin. Seawater environmental parameters were measured as described in the longterm experiment and carbonate chemistry was calculated using CO2SYS (Lewis \& Wallace 1998) (Table 3).

\section{Statistical analysis}

The software packages SPSS (version 11.0), R (R Development Core Team 2011) and OpenBUGS (www.openbugs.info) were used to conduct the analyses. ANCOVA was performed using SPSS to compare size after standardizing the data using the mean initial body length of each group determined in October 2007, while a 2-way ANOVA was applied to compare GI (arcsine transformed). To elucidate whether the experimental conditions affected the number of ova $(\mathrm{N})$ and shifted the month $(t)$ during peak ova number, a non-linear regression of the form, $\mathrm{N}=$ $\gamma / \operatorname{sqrt}\left(2 \pi \sigma^{2}\right) \exp \left(-(t-M)^{2} /\left(2 \sigma^{2}\right)\right)$ was conducted, where $\gamma$ is the maximum number of ova, $M$ is the month when the maximum number of ova was estimated and $\sigma$ is the period when $68 \%$ of the total number of ova are observed. This model was fitted using a Markov Chain Monte Carlo routine based on a Gibbs sampler in OpenBUGS. Four chains were run to approximate convergence, and a total of 4000 uncorrelated samples were saved from the simulations. Priors for the parameters were drawn from a normal distribution, whose parameters were drawn from non-informative uniformly distributed hyperprior. Student's $t$-test was performed to evaluate the effect of $\mathrm{CO}_{2}$ on respiration rate, coelomic fluid $\mathrm{pH},\left[\mathrm{Ca}^{2+}\right]$ and $\left[\mathrm{Mg}^{2+}\right]$.

\section{RESULTS}

\section{Seawater chemistry}

The seawater temperature fluctuated seasonally between 12 and $26^{\circ} \mathrm{C}$ during the 9 mo experimental period (Fig. 1A). The mean seawater pHs during the long-term experiment in the control and high- $\mathrm{CO}_{2}$ conditions were $8.10 \pm 0.05$ and $7.83 \pm 0.05$, respec-
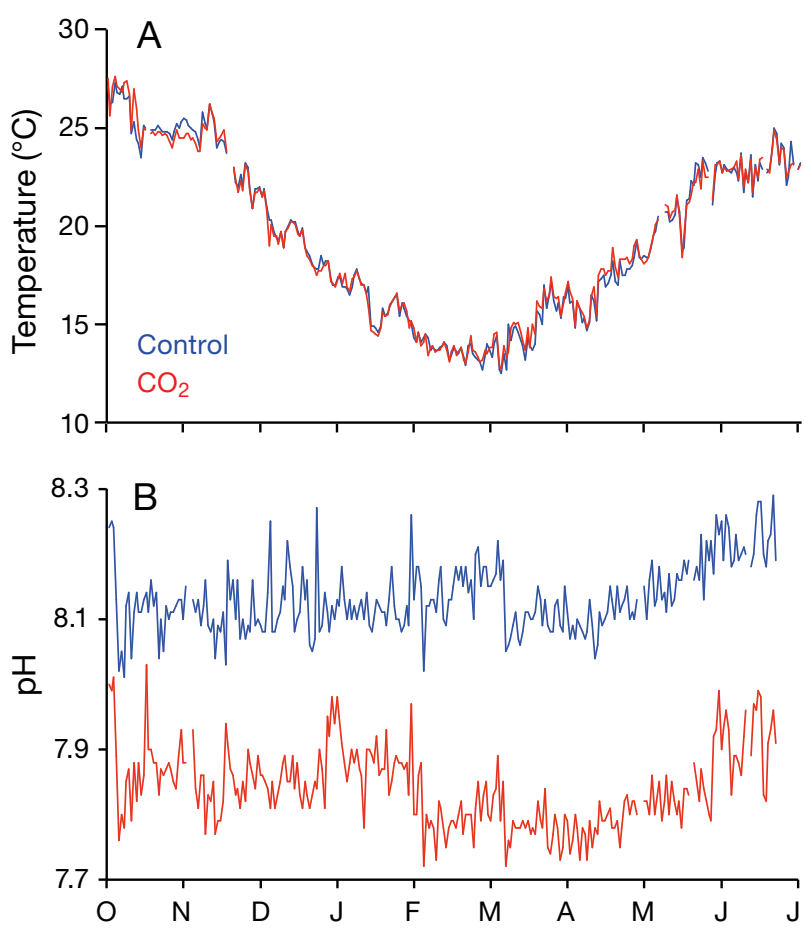

Fig. 1. (A) Seawater temperature and (B) $\mathrm{pH}$ in the control $\left(\mathrm{CO}_{2} 380 \mu \mathrm{atm}\right)$ and high- $\mathrm{CO}_{2}\left(\mathrm{CO}_{2} 1000 \mu \mathrm{atm}\right)$ treatments during the 9 mo experiment 
Table 1. Values (mean \pm SD or range) of seawater chemistry during the experimental period. Seawater pH, temperature and salinity were measured daily for each aquarium. Alkalinity was measured 3 times and the average value $\left(2198 \mu \mathrm{Eq} \mathrm{kg}^{-1}\right) \mathrm{was}_{\mathrm{used}}$ to calculate total CO $\mathrm{CO}_{2}$ $\left(\mathrm{TCO}_{2}\right)$, concentrations of $\mathrm{HCO}_{3}{ }^{-}, \mathrm{CO}_{3}{ }^{2-}$ and $\mathrm{CO}_{2}$, and saturation states of calcite $(\Omega \mathrm{Ca})$ and aragonite $(\Omega \mathrm{Ar})$ in CO2SYS $(\mathrm{Lewis} \& \mathrm{Wallace}$ 1998). Dissociation constants K1 and K2, and $\Omega$ solubility were adopted from Mehrbach et al. (1973) and Mucci (1983), respectively

\begin{tabular}{|lcccccccccc}
\hline Condition & $\mathrm{pH}$ & $\begin{array}{c}\text { Temperature } \\
\left({ }^{\circ} \mathrm{C}\right)\end{array}$ & $\begin{array}{c}\mathrm{TCO}_{2} \\
\left(\mathrm{mmol} \mathrm{kg}^{-1}\right)\end{array}$ & $\begin{array}{c}\mathrm{pCO}_{2} \\
(\mu \mathrm{atm})\end{array}$ & $\begin{array}{c}\mathrm{HCO}_{3}^{-} \\
\left(\mathrm{mmol} \mathrm{kg}^{-1}\right)\end{array}$ & $\begin{array}{c}\mathrm{CO}_{3}{ }^{2-} \\
\left(\mathrm{mmol} \mathrm{kg}^{-1}\right)\end{array}$ & $\begin{array}{c}\mathrm{CO}_{2} \\
\left(\mathrm{mmol} \mathrm{kg}^{-1}\right)\end{array}$ & $\Omega \mathrm{Ca}$ & $\Omega \mathrm{Ar}$ & $\mathrm{Salinity}$ \\
\hline Control & $8.1 \pm 0.1$ & $18.5(12-26)$ & $1977 \pm 35$ & $429 \pm 56$ & $1805 \pm 56$ & $158 \pm 23$ & $15 \pm 2.2$ & $3.8 \pm 0.6$ & $2.4 \pm 0.4$ & $35.0 \pm 0.4$ \\
$\mathrm{CO}_{2}$ & $7.83 \pm 0.05$ & $18.5(12-26)$ & $2096 \pm 29$ & $919 \pm 122$ & $1976 \pm 40$ & $89 \pm 16$ & $31 \pm 5.3$ & $2.1 \pm 0.4$ & $1.4 \pm 0.3$ & $34.9 \pm 0.4$ \\
\hline
\end{tabular}

tively (Table 1, Fig. 1B). The seawater carbonate chemistry in control and high- $\mathrm{CO}_{2}$ conditions is shown in Table 1.

\section{Survival, growth, gonad development and egg reproduction}

No individuals died during the 9 mo experimental period in either condition. The standardized size of sea urchins did not differ significantly between conditions throughout the experimental period (Fig. 2A, ANCOVA, Table 2). The wet weights of the calcium
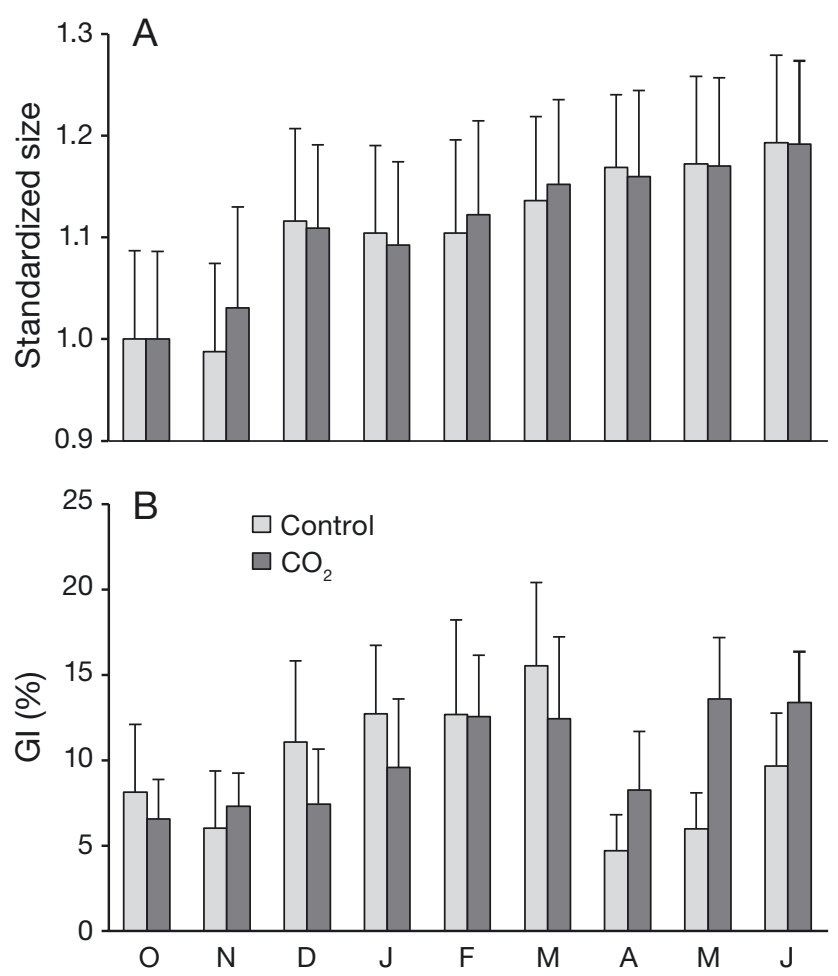

Fig. 2 Hemicentrotus pulcherrimus. Mean \pm SD (A) standardized test size and (B) gonad index $\left(\mathrm{GI}_{;} \mathrm{N}=10\right)$ of sea urchins reared under control and high- $\mathrm{CO}_{2}$ conditions. Size was standardized by dividing the test diameter data of each group measured every month by the mean value of each group determined in October 2007 carbonate body (test + Aristotle's lantern) and the soft body were not affected by treatment (Fig. 3). The GI was not significantly affected by high $\mathrm{CO}_{2}$, but there was an interaction between month and experimental condition (Fig. 2B, 2-way ANOVA, Table 2). Because the gonad size of sea urchins does not necessarily relate to the progress of gametogenesis alone (Walker et al. 1998, 2007), we examined the percentage distribution of each gonad developmental stage, and found that germinal stages were more advanced in the control individuals compared with the high- $\mathrm{CO}_{2}$ groups at the same sampling times in January through
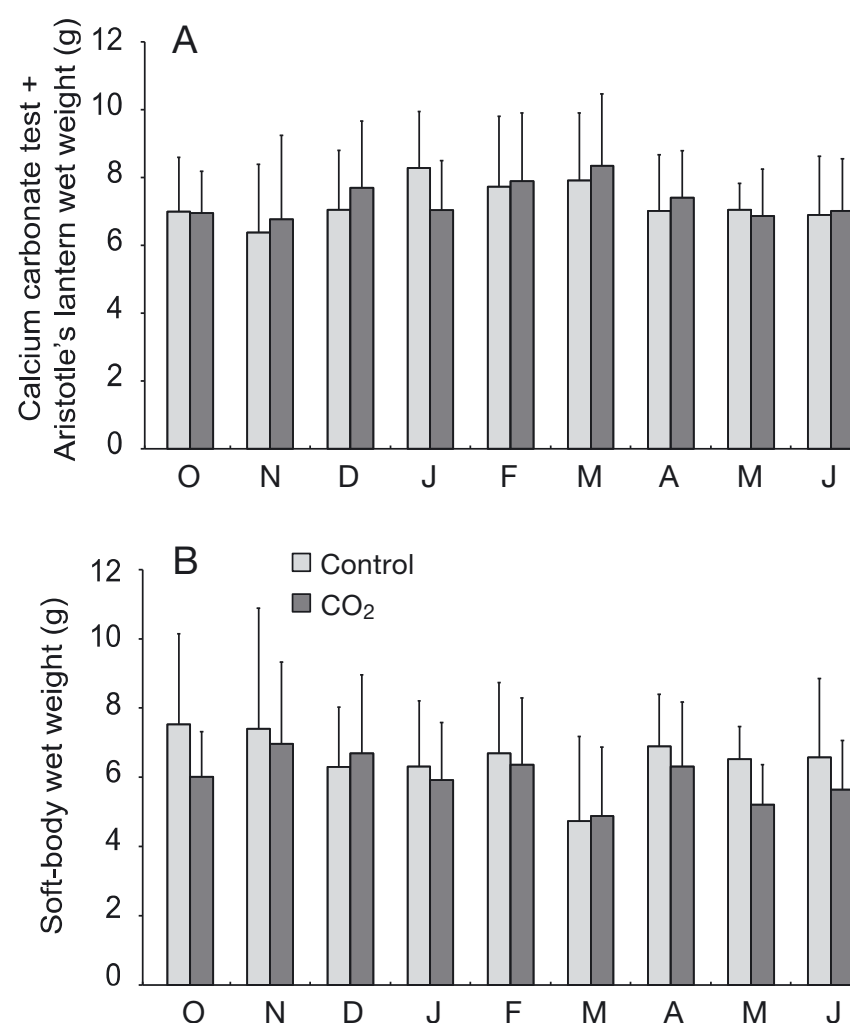

Fig. 3. Hemicentrotus pulcherrimus. Mean (A) calcium carbonate test + Aristotle's lantern wet weight and (B) soft-body wet weight (= whole body wet weight - (gonad wet weight + Aristotle's lantern wet weight)) of sea urchins reared under the control and high- $\mathrm{CO}_{2}$ conditions. $\mathrm{N}=10$ 
Table 2. Effects of $\mathrm{CO}_{2}$ and exposure time on standardized sea urchin size (ANCOVA), and arcsine-transformed gonad index (GI) (2-way ANOVA)

\begin{tabular}{|lccccc|}
\hline Source & Type III SS & df & MS & $F$ & $\mathrm{p}$ \\
\hline Standardized size & & & & & \\
Corrected model & $4.005^{*}$ & 3 & 1.335 & 166.858 & 0.000 \\
$\mathrm{CO}_{2}$ & $4.88 \times 10^{-5}$ & 1 & $4.88 \times 10^{-5}$ & 0.006 & 0.938 \\
Time & 3.852 & 1 & 3.852 & 481.522 & 0.000 \\
$\mathrm{CO}_{2} \times$ Time & 0.004 & 1 & 0.004 & 0.520 & 0.471 \\
Residuals & 9 & 1125 & 0.008 & & \\
Total & 1322.079 & 1129 & & & \\
Arcsine GI & & & & & \\
Corrected model & $0.164^{* *}$ & 17 & 0.010 & 6.740 & 0.000 \\
$\mathrm{CO}_{2}$ & 0.002 & 1 & 0.002 & 1.212 & 0.272 \\
Time & 0.107 & 8 & 0.013 & 9.359 & 0.000 \\
$\mathrm{CO}_{2} \times$ Time & 0.055 & 8 & 0.007 & 4.811 & 0.000 \\
Residuals & 0.232 & 162 & 0.001 & & \\
Total & 2.132 & 180 & & & \\
${ }^{*} \mathrm{R}^{2}=0.308$ (adjusted $\mathrm{R}^{2}=0.306$ ) ${ }^{* *} \mathrm{R}^{2}=0.414$ (adjusted $\mathrm{R}^{2}=0.353$ ) \\
\hline
\end{tabular}

$\mathrm{h}^{-1} \mathrm{~g}^{-1}$ ) were slightly but not significantly higher compared with the controls $(0.588 \pm$ $0.24 \mu \mathrm{mol} \mathrm{l} \mathrm{l}^{-1} \mathrm{~h}^{-1} \mathrm{~g}^{-1}$ ) (Student's $t$-test, $\mathrm{p}=$ 0.22; Fig. 6). Coelomic fluid $\mathrm{pH}$ of high- $\mathrm{CO}_{2}$ sea urchins $(7.03 \pm 0.29)$ was significantly lower ( $t$-test, $\mathrm{p}<0.001)$ compared with the control (7.61 \pm 0.11 ; Fig. 6). The $\left[\mathrm{Mg}^{2+}\right]$ of the coelomic fluid was significantly lower in the high- $\mathrm{CO}_{2}$ sea urchins $\left(48.66 \pm 1.82 \mathrm{mmol} \mathrm{l^{-1 }}\right)$ compared with the control sea urchins (50.38 $\pm 1.38 \mathrm{mmol} \mathrm{l}^{-1}$, Student's $t$-test, $\mathrm{p}=0.03$; Fig. 6), whereas $\left[\mathrm{Ca}^{2+}\right]$ was not affected (control: $9.67 \pm 0.38 ; \mathrm{CO}_{2}: 9.96 \pm 0.31$, Student's t-test, $\mathrm{p}=0.06$, Fig. 6).

\section{Feeding}

April (Fig. 4). The number of ova peaked in February in the control sea urchins (Fig. 5A,Bii,Civ), whereas it peaked 1 mo later in the high- $\mathrm{CO}_{2}$ urchins (Fig. 5A,Bii,Cvi). No significant difference was detected for the maximum numbers of ova and period of time when the ova were observed between the control and high- $\mathrm{CO}_{2}$ conditions (Fig. 5A,Bii,Biii). Spawning was observed on 16 February and 13 March in the control and high- $\mathrm{CO}_{2}$ conditions, respectively.

\section{Respiration, $\mathrm{pH}$ and ion concentration of the coelomic fluid}

Respiration rates of the sea urchins exposed for 9 mo under high $-\mathrm{CO}_{2}$ conditions $\left(0.783 \pm 0.35 \mu \mathrm{mol} \mathrm{l}^{-1}\right.$
The seawater carbonate chemistry of the short-term experiment is shown in Table 3. Feeding rate was significantly suppressed by high $\mathrm{CO}_{2}$ (repeated-measures 2-way ANOVA, $F_{1,18}=22.33, \mathrm{p}<0.001$ ) and there was a significant effect of time $\left(F_{7,126}=4.14, \mathrm{p}<\right.$ 0.001). The interaction of $\mathrm{CO}_{2}$ concentration and time was significant $\left(F_{7,126}=3.30, \mathrm{p}=0.003\right.$; Fig. 7$)$.

\section{DISCUSSION}

The present study demonstrated that long-term exposure to $1000 \mu \mathrm{atm} \mathrm{CO}_{2}$ delayed both gametogenesis and spawning of the sea urchin Hemicentrotus pulcherrimus, and significantly decreased $\mathrm{pH}$ and $\left[\mathrm{Mg}^{2+}\right]$ of the coelomic fluid. However, survival,

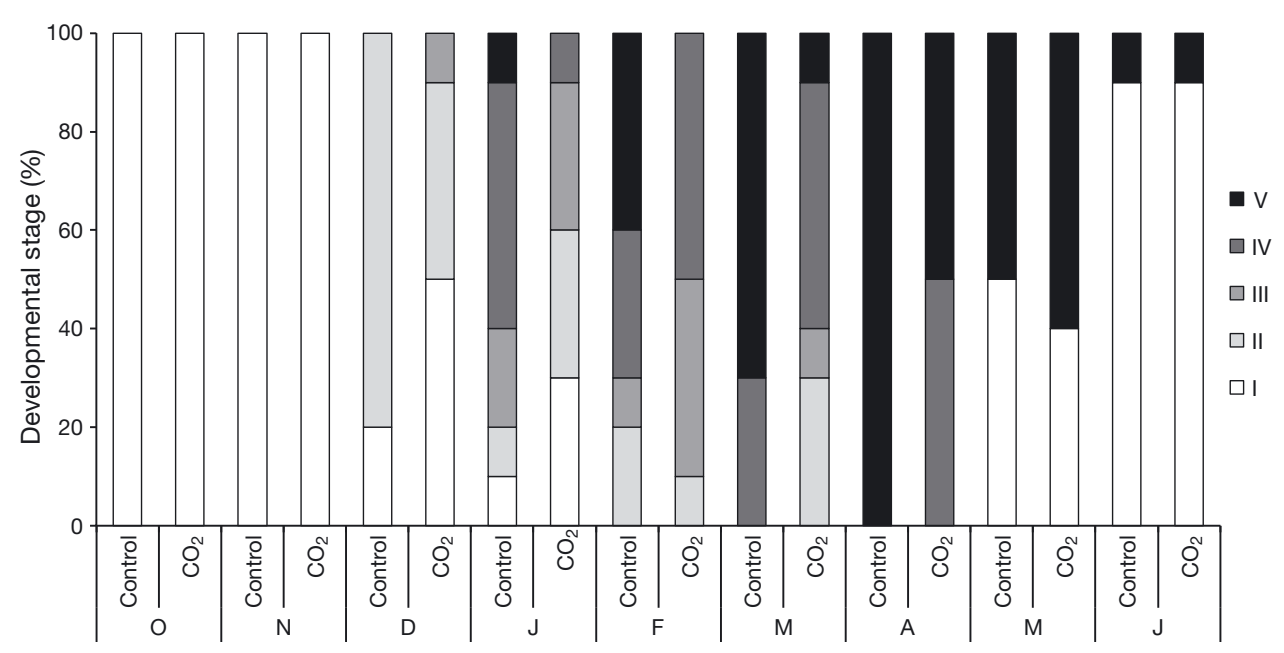

Fig. 4. Hemicentrotus pulcherrimus. Percent distribution of the gonad developmental stages reared under control and high$\mathrm{CO}_{2}$ conditions $(\mathrm{N}=10)$. The gametogenesis stages were determined according to Fuji (1960): stage I (spent recovering stage); stage II (growing stage); stage III (pre-mature stage); stage IV (mature stage); and stage V (spent stage) 

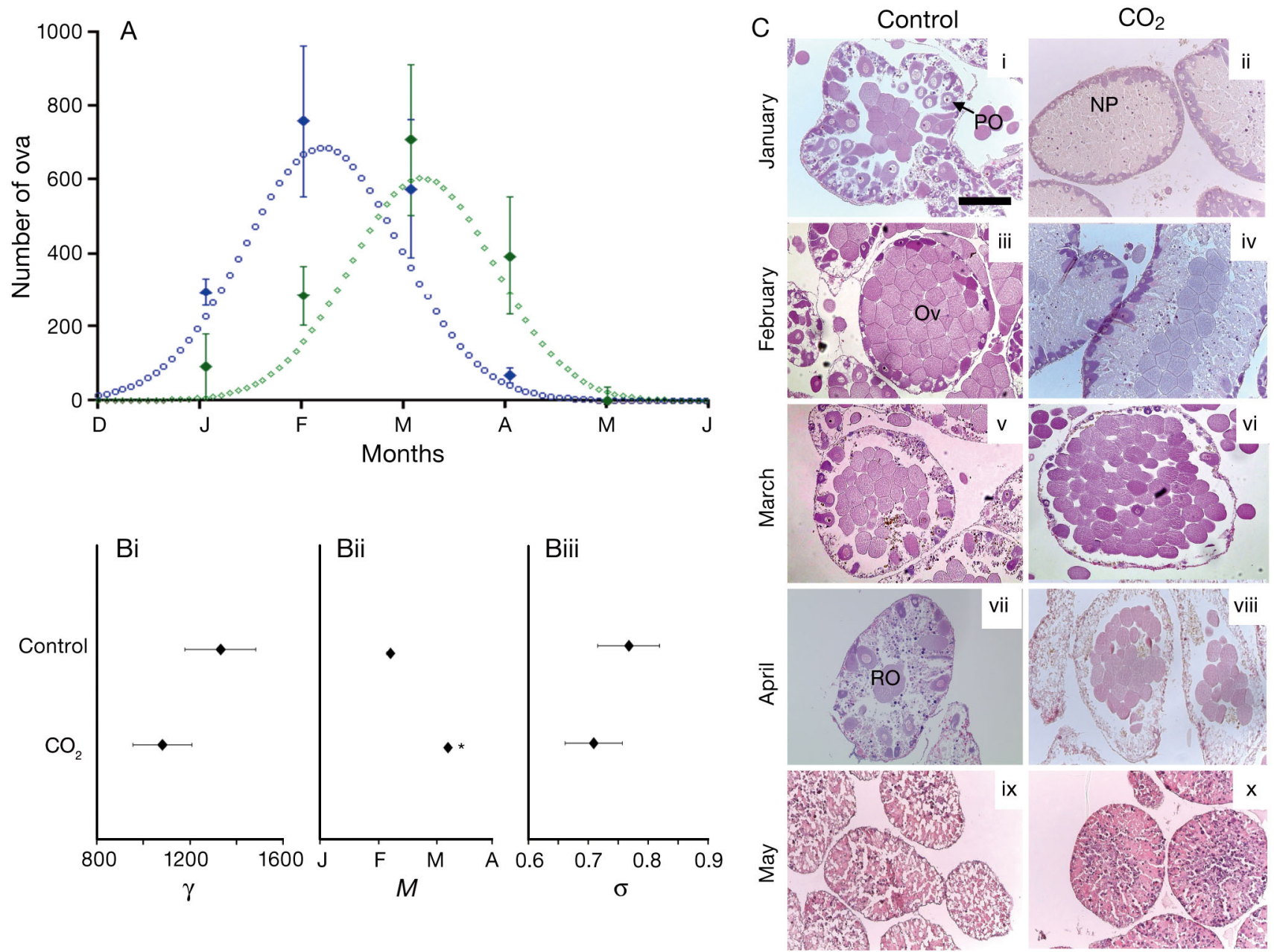

Fig. 5. Hemicentrotus pulcherrimus. (A) Mean $( \pm \mathrm{SD})$ number of ova per cross-section of sea urchin ovary reared under control (blue) and high- $\mathrm{CO}_{2}$ conditions (green). $\mathrm{N}=3$ in January, April, May, $\mathrm{N}=3$ to 6 in February, March. (Bi) Maximum number of ova, $\gamma_{1}$ (Bii) mean month during the maximum number of ova, $M$, and (Biii) the mean period that the ova were observed, $\sigma$, in the control and high- $\mathrm{CO}_{2}$ conditions. ${ }^{*}$ Significant difference from control. (C) Photomicrographs showing ovarian development in the control and high- $\mathrm{CO}_{2}$ groups. Ovarian gametogenesis stages were determined according to Fuji (1960) (see Fig. 4 legend): stage I $(\mathrm{ix}, \mathrm{x})$; stage II (ii); stage III (i,iv); stage IV (iii,vi); and stage V (v,vii,viii). Scale $(200 \mu \mathrm{m})$ applies to all photomicrographs. NP: nutritive phagocyte; PO: primary ooctyte; Ov: ovum (mature egg); RO: residual oocyte

growth and respiration rate were not affected by high $\mathrm{CO}_{2}$. In addition, the short-term experiment demonstrated that exposure to 1000 atm $\mathrm{CO}_{2}$ suppressed food intake of this sea urchin.

\section{Effects on gonad growth}

Long-term (9 mo) exposure to 1000 uatm $\mathrm{CO}_{2}$ delayed both gametogenesis and spawning of Hemicentrotus pulcherrimus by 1 mo without affecting the maximum number of ova. The timing of spawning and larval release is considered to converge to when biotic and abiotic environmental conditions are most suitable for the survival of spawning females, embryos, larvae and settling stages (Morgan 1995). Hence, a temporal change in gametogenesis and spawning may result in reduced fitness of larvae due to the reduced survival rate at the sub-optimal temperature and phytoplankton food condition (Morgan \& Christy 1994).

Gametogenesis of sea urchins is known to be governed by a number of factors including environmental conditions (e.g. temperature, photoperiod) and nutritional status of individuals (Walker \& Lesser 1998, Yamamoto et al. 1988), and when energy intake is limited, animals often decrease reproductive effort (Schneider 2004). Siikavuopio et al. (2007) demonstrated that hypercapnia (5000-6000 $\mu \mathrm{atm} \mathrm{CO}_{2}$ ) 

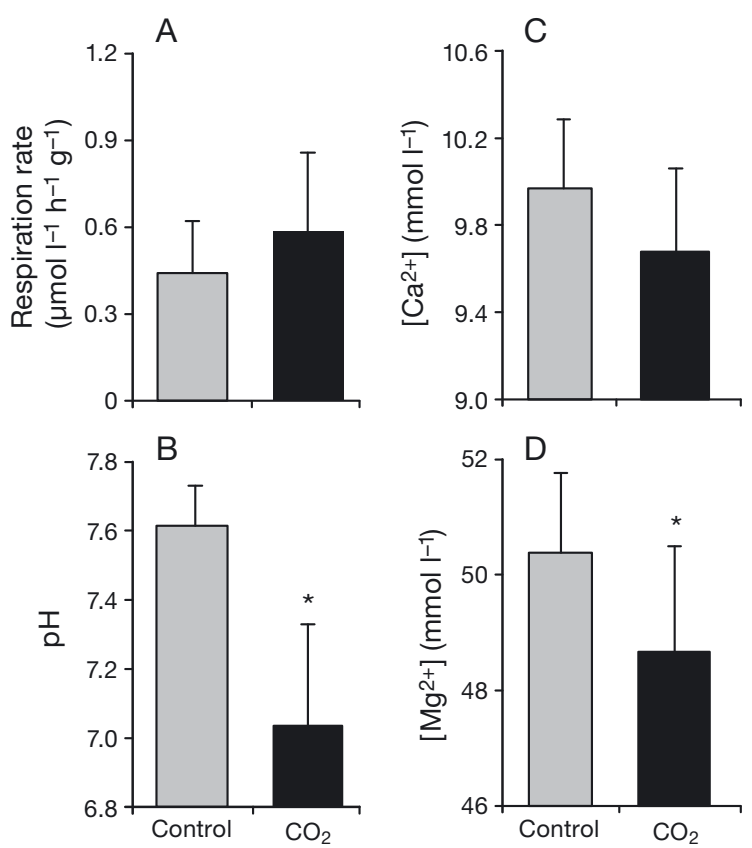

Fig. 6. Hemicentrotus pulcherrimus. Mean $\pm \mathrm{SE}$ (A) respiration rate, (B) coelomic fluid $\mathrm{pH},(\mathrm{C})\left[\mathrm{Ca}^{2+}\right]$ and (D) $\left[\mathrm{Mg}^{2+}\right]$ of sea urchins reared under control and high- $\mathrm{CO}_{2}$ conditions

for 9 mo. $\mathrm{N}=13$. ${ }^{*}$ Significant difference from control

suppressed both gonad growth and food conversion efficiency of the sea urchin Strongylocentrotus droebachiensis. The finding of a significant positive correlation between gonad growth and food intake in $S$. droebachiensis (Christiansen \& Siikavuopio 2007) supports the speculation by Siikavuopio et al. (2007). In the short-term experiment in the present study, we also observed a reduction in food intake in high- $\mathrm{CO}_{2}$ urchins (Fig. 7). Since the effect of $\mathrm{CO}_{2}$ on food intake was measured in a short-term experiment, we were not able to determine whether the suppression of food intake lasted for the whole experiment; however, from a recent study we found that the food intake of Hemicentrotus pulcherrimus declined with time and remained significantly lower compared with controls for several months (R. Yin et al. unpubl. data). Similarly, decreased ingestion and gonad dry weight were also found in $S$. drobachiensis reared for

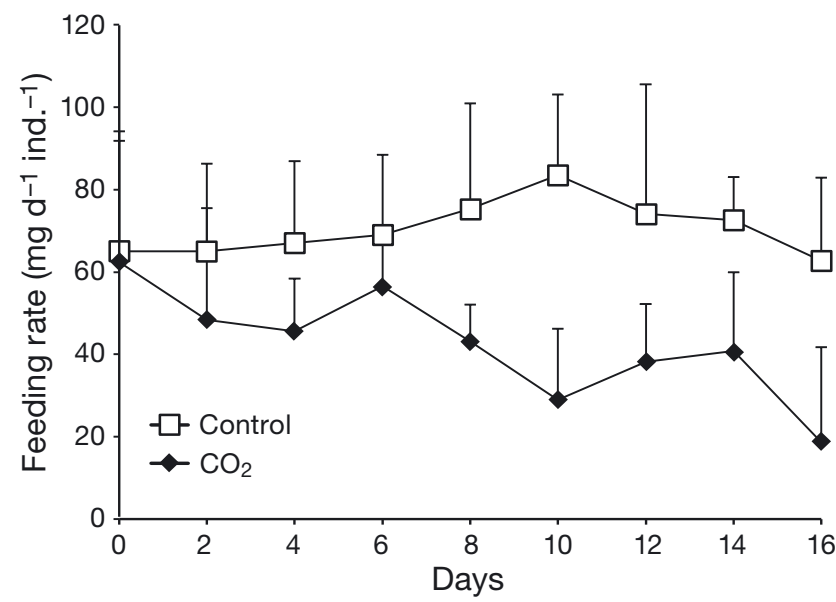

Fig. 7. Hemicentrotus pulcherrimus. Mean \pm SE feeding rate of sea urchins reared under control and high- $\mathrm{CO}_{2}$ conditions. $\mathrm{N}=10$

45 d under 2800-3800 $\mu$ atm $\mathrm{CO}_{2}$, (Stumpp et al. 2012). Before gametogenesis begins, the major yolk protein (MYP) synthesized from proteins of ingested food is stored in the nutrient phagocytes (NP), which are the somatic cells within the germinal epithelium (Walker et al. 2005). MYP is consumed for egg and sperm production during gametogenesis, and also serves as a nutrient source for early development after fertilization (Unuma et al. 2003). Since both MYP production and NP growth are stimulated by the availability of food (de Jong-Westman et al. 1995, Lawrence et al. 1997), we speculate that the reduced feeding under the high- $\mathrm{CO}_{2}$ conditions disrupted MYP synthesis, leading to a delay in ovum growth to maturity. The mechanisms underlying the feeding suppression by $\mathrm{CO}_{2}$ remain unknown; reduced feeding efficacy due to partial weakening or dissolution of the masticating apparatus (Aristotle's lantern) might be involved because sea urchin teeth are composed of high-Mg calcite, a highly acid-soluble form of $\mathrm{CaCO}_{3}$ (Killian et al. 2011). A more recent study revealed that the movement speed of $H$. pulcherrimus during food searching was reduced by high $\mathrm{CO}_{2}$ compared with the control (R. Yin et al. unpubl. data).

Table 3. Values of seawater chemistry during the short-term experiment. $\mathrm{pH}$ and temperature were measured daily for each tank. Salinity was measured daily and adjusted to $35 \pm 0.5$ by adding distilled when necessary. Alkalinity $\left(2198 \mu \mathrm{Eq} \mathrm{kg}^{-1}\right.$ seawater) was used to calculate the other parameters in CO2SYS. Dissociation constants K1 and K2 were adopted from Mehrbach et al. (1973)

\begin{tabular}{|c|c|c|c|c|c|c|c|}
\hline Condition & $\mathrm{pH}$ & $\begin{array}{l}\text { Temperature } \\
\left({ }^{\circ} \mathrm{C}\right)\end{array}$ & $\begin{array}{c}\mathrm{TCO}_{2} \\
\left(\mathrm{mmol} \mathrm{kg}^{-1}\right)\end{array}$ & $\begin{array}{c}\mathrm{pCO}_{2} \\
(\mu \mathrm{atm})\end{array}$ & $\begin{array}{c}\mathrm{HCO}_{3}^{-} \\
\left(\mathrm{mmol} \mathrm{kg}^{-1}\right)\end{array}$ & $\begin{array}{c}\mathrm{CO}_{3}^{2-} \\
\left(\mathrm{mmol} \mathrm{kg}^{-1}\right)\end{array}$ & $\begin{array}{c}\mathrm{CO}_{2} \\
\left(\mathrm{mmol} \mathrm{kg}^{-1}\right)\end{array}$ \\
\hline Control & $8.20 \pm 0.02$ & $18.2 \pm 0.11$ & $1947 \pm 13$ & $348 \pm 23$ & $1758 \pm 20$ & $177 \pm 8$ & $11.9 \pm 0.8$ \\
\hline $\mathrm{CO}_{2}$ & $7.85 \pm 0.02$ & $18.0 \pm 0.15$ & $2096 \pm 8$ & $873 \pm 48$ & $1976 \pm 10$ & $89 \pm 4$ & $29.7 \pm 1.6$ \\
\hline
\end{tabular}




\section{Effects on physiology: respiration, coelomic fluid $\mathrm{pH}, \mathrm{Ca}^{2+}$ and $\mathrm{Mg}^{2+}$ concentrations}

We found that $1000 \mu \mathrm{atm} \mathrm{CO}_{2}$ did not affect respiration rate, which is consistent with the results observed in the sea urchin Strongylocentrotus droebachiensis reared for $45 \mathrm{~d}$ under 1007-1431 $\mu \mathrm{atm}$ (Stumpp et al. 2012). Metabolic suppression under high- $\mathrm{CO}_{2}$ conditions has been proposed as an adaptive strategy to suppress ATP demand (Fabry et al. 2008). However, metabolic responses of marine organisms are highly variable between species; several studies reported no effect (Gutowska et al. 2008, Melzner et al. 2009) or even an increase (Wood et al. 2008, Beniash et al. 2010) under high $\mathrm{CO}_{2}$ conditions.

A significant reduction in coelomic fluid $\mathrm{pH}$ (0.6 units) was observed in Hemicentrotus pulcherrimus exposed to $1000 \mu$ atm $\mathrm{CO}_{2}(\mathrm{pH} 7.83)$ in our study. Miles et al. (2007) reported the lack of acidbase compensation capacity of the sea urchin Psammechinus miliaris reared under high- $\mathrm{CO}_{2}$ conditions (pH 7.44) for $8 \mathrm{~d}$. A reduction of the coelomic fluid $\mathrm{pH}$ was also observed in $S$. droebachiencis reared in $1353 \mu \mathrm{atm} \mathrm{CO}_{2}$ seawater for $5 \mathrm{~d}$ (Spicer et al. 2011). Melzner et al. (2009) suggested that less active organisms such as echinoderms and bivalve mollusks have less capacity to regulate the acid-base balance, and are therefore more vulnerable to high $\mathrm{CO}_{2}$. On the other hand, full compensation of coelomic fluid acidosis was reported in $S$. drobachiensis exposed for both 10 and $45 \mathrm{~d}$ in 1007-1431 $\mu$ atm $\mathrm{CO}_{2}$ (Stumpp et al. 2012). The authors suggested that the sea urchin was pre-adapted to high $\mathrm{CO}_{2}$ due to natural variability in $\mathrm{pCO}_{2}$ by upwelling in its habitat.

In addition to the significant decrease in coelomic fluid $\mathrm{pH}$, we also observed a subtle but significant decrease in coelomic fluid $\left[\mathrm{Mg}^{2+}\right]$ in high- $\mathrm{CO}_{2}$ sea urchins (Fig. 6). This contrasts with previous findings that demonstrated an increase in coelomic fluid $\left[\mathrm{Mg}^{2+}\right]$ in Psammechinus miliaris (Miles et al. 2007) and an increase in $\left[\mathrm{Ca}^{2+}\right]$ in Strongylocentrotus drobachiensis exposed to high- $\mathrm{CO}_{2}$ conditions (Spicer et al. 2011). Increases of $\left[\mathrm{Mg}^{2+}\right]$ and $\left[\mathrm{Ca}^{2+}\right]$ have been suggested to be due to test dissolution, which functions as a compensation mechanism against extracellular acidosis. However, since the weight of calcium carbonate body or $\left[\mathrm{Ca}^{2+}\right]$ was not affected by high $\mathrm{CO}_{2}$ in this study, it seems unlikely that Hemicentrotus pulcherrimus relies on test dissolution to restore coelomic fluid $\mathrm{pH}$. The change in $\left[\mathrm{Mg}^{2+}\right]$ under elevated $\mathrm{CO}_{2}$ conditions seems to be highly species specific; a decrease (in $H$. pulcher- rimus, present study), an increase (in P. mirabilis; Miles et al. 2007) and no change (in S. drobachiensis; Spicer et al. 2011) have been reported for various species, and the reason for this variability is unclear.

\section{Effects of survival and growth}

Our study demonstrated that neither survival nor growth rate of Hemicentrotus pulcherrimus (adult specimens, mean initial body weight $14.5 \mathrm{~g}$ ) was affected when reared for 9 mo under high- $\mathrm{CO}_{2}$ conditions $\left(\mathrm{CO}_{2} 1000\right.$ uatm, pH 7.83). In contrast, when the same species, with a mean initial body weight of $0.84 \mathrm{~g}$, was exposed for 26 wk to $200 \mu$ atm above ambient $\mathrm{CO}_{2}$ (experimental: $560 \mu \mathrm{atm}$, seawater $\mathrm{pH}$ 7.897-7.902; control: 360 uatm, seawater pH 7.9367.945), it showed reductions in both survival and growth (Shirayama \& Thornton 2005). Similar to our findings for $H$. pulcherrimus, growth and survival rates of the green sea urchin Strongylocentrotus droebachiensis (mature specimens, initial body weight $51.3 \mathrm{~g}$ ) were unaffected when exposed to very high $\mathrm{CO}_{2}\left(\mathrm{pH}\right.$ 6.89, $\left.\mathrm{pCO}_{2} 8000 \mu \mathrm{atm}\right)$ for about $2 \mathrm{mo}$ (Siikavuopio et al. 2007). Additionally, a recent study reported that the growth rate of the sea star Pisaster ochraceus (juvenile, initial body weight 3-7 g) was significantly stimulated when reared for 2 mo under high- $\mathrm{CO}_{2}$ conditions $\left(\mathrm{CO}_{2} 780 \mu \mathrm{atm}, \mathrm{pH}\right.$ 7.79) compared with the control $\left(\mathrm{CO}_{2} 380\right.$ uatm, $\mathrm{pH}$ 7.88) (Gooding et al. 2009). These differences may be attributable to the difference in life stages (juvenile vs. mature), experimental period (2-9 mo) and/or species-specific tolerance to high $\mathrm{CO}_{2}$ conditions. However, it should also be noted that the $\mathrm{pH}$ levels of control seawater varied between studies, possibly due to different seawater alkalinity or failure in controlling seawater carbonate chemistry or both, which makes it difficult to directly compare the results of these studies.

\section{Effects on energy balance and sea urchin population}

In the present study, ocean acidification reduced the energy intake of Hemicentrotus pulcherrimus, while energy of maintenance (respiration) and growth were not affected. Therefore, we suggest that the energy cost of reduced feeding increases the time until sea urchins acquire enough amount of energy to become fully mature and produce mature 


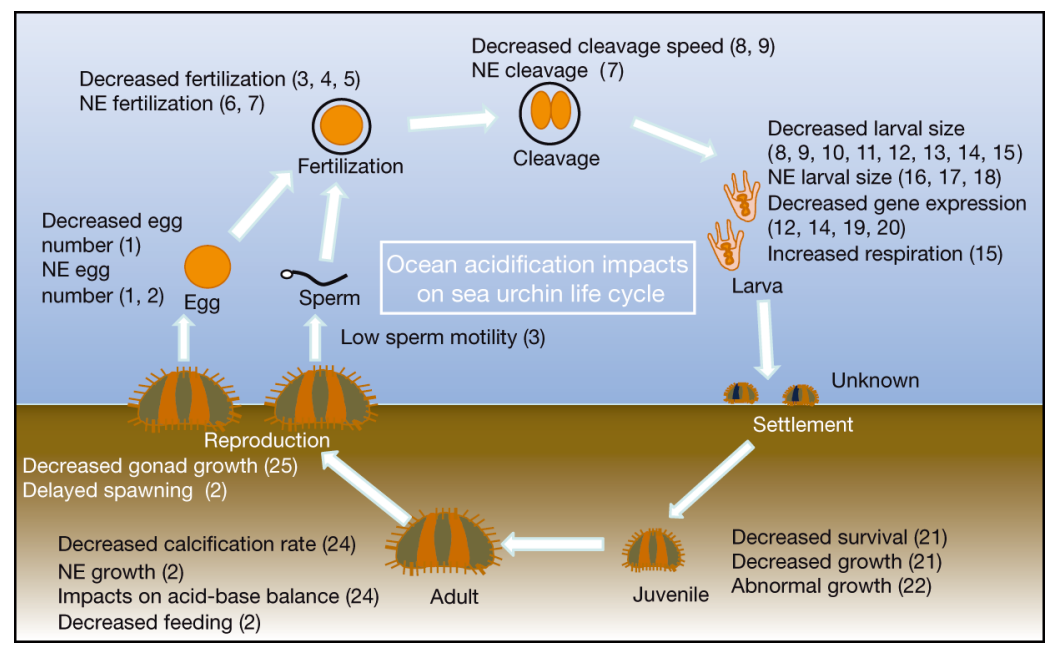

Fig. 8. Effect of ocean acidification on the sea urchin life cycle. NE: no effect. Numbers show references-1: Dupont et al. (2012); 2: present study; 3: Havenhand et al. (2008); 4: Byrne et al. (2010a); 5: Reuter et al. (2011), 6: Byrne et al. (2009); 7: Byrne et al. (2010b); 8: Kurihara \& Shirayama (2004); 9: Kurihara et al. (2004); 10: Clark et al. (2009); 11: Sheppard Brennand et al. (2010); 12: O'Donnell et al. (2010); 13: Sunday et al. (2011); 14: Stumpp et al. (2011a); 15: Stumpp et al. (2011b); 16: Yu et al. (2011); 17: Martin et al. (2011); 18: Catarino et al. (2012); 19: Todgham \& Hofmann (2009); 20: Kurihara et al. (2012); 21: Shirayama \& Thornton (2005); 22: Byrne et al. (2011); 23: Ries et al. (2009); 24: Miles et al. (2007); 25: Stumpp et al. (2012)

eggs. Additionally, though fecundity (number of eggs) of $H$. pulcherrimus was not affected by ocean acidification, potential impacts on egg quality (e.g. egg size, nutrient content) are suggested. A number of studies have documented the influence of adult nutrition on egg 'quality' in marine invertebrates, and egg size has been revealed to have a direct correlation with maternal nutrition (Thompson 1983, George et al. 1990, Jaeckle 1995). Bayne et al. (1978) demonstrated that stressed mussels release fewer and lower quality eggs compared to unstressed individuals. Earlier studies on H. pulcherrimus reported negative impacts of ocean acidification on early development, including delayed cleavage and smaller larval size (Kurihara \& Shirayama, 2004, Kurihara et al. 2012). Taking into account that the population size of sea urchins (and many other marine invertebrates) is largely determined by the number of offspring, fertilization success and embryonic survival (Kurihara 2008), these results imply that ocean acidification will threaten H. pulcherrimus at a community level. Negative impacts have been reported for most, if not all, sea urchin species (Fig. 8; Byrne et al. 2009, 2010b, Dupont et al. 2010). Different vulnerabilities of each life stage to elevated $\mathrm{CO}_{2}$ might lead to restructuring of local sea urchin fauna. Extrapolating from the observation that drastic phase shifts ensued when the size of sea urchin populations was increased (Estes \& Palmisano 1974, Jackson et al. 2001), or when sea urchins declined in abundance on coral reefs due to disease outbreaks (Hughes et al. 2007), changing sea urchin populations as a result of ocean acidification can be envisaged as having far-reaching ecological consequences.
Acknowledgements. We gratefully acknowledge Dr. M. Washio and Dr. T. Minokawa, Research Center for Marine Biology, Tohoku University, for their help in collecting specimens. We thank Dr. Y. Hiratsuka, University of the Ryukyus, for his helpful comments.

\section{LITERATURE CITED}

Bayne BL, Hollland DL, Moore MN, Lowe DM, Widdows J (1978) Further studies on the effects of stress in the adult on the eggs of Mytillus edulis. J Mar Biol Assoc UK 58: 825-841

Beniash E, Ivanina A, Lieb NS, Kurochkin I, Sokolova IM (2010) Elevated level of carbon dioxide affects metabolism and shell formation in oysters Crassostrea virginica. Mar Ecol Prog Ser 419:95-108

Bibby R, Widdicombe S, Parry H, Spicer J, Pipe R (2008) Effects of ocean acidification on the immune response of the blue mussel Mytilus edulis. Aquat Biol 2:67-74

Byrne M, Ho M, Selvakumaraswamy P, Nguyen HD, Dworjanyn SA, Davis AR (2009) Temperature, but not $\mathrm{pH}$, compromises sea urchin fertilization and early development under near-future climate change scenarios. Proc R Soc Lond B Biol Sci 276:1883-1888

Byrne M, Soars NA, Selvakumaraswamy P, Dworjanyn SA, Davis AR (2010a) Sea urchin fertilization in a warm, acidified and high $\mathrm{pCO}_{2}$ ocean across a range of sperm densities. Mar Environ Res 69:234-239

Byrne M, Soars NA, Ho MA, Wong E and others (2010b) Fertilization in a suite of coastal marine invertebrates from SE Australia is robust to near-future ocean warming and acidification. Mar Biol 157:2061-2069

Byrne M, Ho M, Wong E, Soars NA and others (2011) Unshelled abalone and corrupted urchins: development of marine calcifiers in a changing ocean. Proc R Soc Lond B Biol Sci 278:2376-2383

Caldeira K, Wickett ME (2003) Anthropogenic carbon and ocean $\mathrm{pH}$. Nature 425:365

Catarino AI, Ridder CD, Gonzalez M, Gallardo P, Dubois P (2012) Sea urchin Arbacia dufresnei (Blainville 1825) larvae response to ocean acidification. Polar Biol 35: 455-461 
Christiansen J, Siikavuopio SI (2007) The relationship between feed intake and gonad growth of single and stocked green sea urchin (Strongylocentrotus droebachiensis) in a raceway culture. Aquaculture 262: 163-167

Clark D, Lamare M, Barker M (2009) Response of sea urchin pluteus larvae (Echinodermata: Echinoidea) to reduced seawater $\mathrm{pH}$ : a comparison among a tropical, temperate, and a polar species. Mar Biol 156:1125-1137

de Jong-Westman M, March BE, Carefoot TH (1995) The effect of different nutrient formulations in artificial diets on gonad growth in the sea urchin Strongylocentrotus droebachiensis. Can J Zool 73:1495-1502

> Domenici P, Allan B, McCormick MI, Munday PL (2012) Elevated carbon dioxide affects behavioural lateralization in a coral reef fish. Biol Lett 8:78-81

> Dupont S, Ortega-Martínez O, Thorndyke M (2010) Impact of near-future ocean acidification on echinoderms. Ecotoxicology 19:449-462

> Dupont S, Dorey N, Stumpp M, Melzner F, Thorndyke M (2012) Long-term and trans-life-cycle effects of exposure to ocean acidification in the green sea urchin Strongylocentrotus drobachiensis. Mar Biol doi:10.1007/s00227012-1921-x

Estes JA, Palmisano JF (1974) Sea otters: their role in structuring nearshore communities. Science 185:1058-1060

Fabry VJ, Seibel BA, Feely RA, Orr JC (2008) Impacts of ocean acidification on marine fauna and ecosystem processes. ICES J Mar Sci 65:414-432

Fitzer SC, Caldwell GS, Close AJ, Clare AS, Upstill-Goddard RC, Bentley MG (2012) Ocean acidification induces multi-generational decline in copepod naupliar production with possible conflict for reproductive resource allocation. J Exp Mar Biol Ecol 418-419:30-36

Fuji A (1960) Studies on the biology of the sea urchin. I. Superficial and histological gonadal changes in the gametogenic process of two sea urchins, Strongylocentrotus nudus and S. internedius. Bull Fac Fish Hokkaido Univ 11:1-14

> Gazeau F, Quiblier C, Jansen JM, Gattuso JP, Middelburg JJ, Heip CH (2007) Impact of elevated $\mathrm{CO}_{2}$ on shellfish calcification. Geophys Res Lett 34:L07603, doi:10.1029/ 2006GL028554

George SB, Cellario C, Fenaux L (1990) Population differences in egg quality of Arbacia lixula (Echinodermata: Echinoidea): proximate composition of eggs and larval development. J Exp Mar Biol Ecol 141:107-118

> Gooding RA, Harley CDG, Tang E (2009) Elevated water temperature and carbon dioxide concentration increase the growth of keystone echinoderm. Proc Natl Acad Sci USA 106:9316-9321

Gutowska MA, Pörtner HO, Melzner F (2008) Growth and calcification in the cephalopod Sepia officinalis under elevated seawater $\mathrm{pCO}_{2}$. Mar Ecol Prog Ser 373:303-309

> Havenhand JN, Butler FR, Thorndyke MC, Williamson JE (2008) Near-future levels of ocean acidification reduce fertilization success in sea urchin. Curr Biol 18: R651-R652

> Hofmann GE, Barry JP, Edmunds PJ, Gates RD, Hutchins DA, Klinger T, Sewell MA (2010) The effect of ocean acidification on calcifying organisms in marine ecosystems: an organism-to-ecosystem perspective. Annu Rev Ecol Evol Syst 41:127-147

> Hughes TP, Rodrigues MJ, Bellwood DR, Ceccarelli D, Hoegh-Guldberg O, and others (2007) Phase shifts, her- bivory and the resilience of coral reefs to climate change. Curr Biol 17:360-365

IPCC (2007) The fourth assessment report of the Intergovernmental Panel on Climate Change. Cambridge University Press, Cambridge

Jackson JBC, Kirby MX, Berger WH, Bjorndal KA, Botsford LW, and others (2001) Historical overfishing and the recent collapse of coastal ecosystems. Science 293: 629-637

Jaeckle WB (1995) Variation in the size, energy content, and biochemical composition of invertebrate eggs: correlates to the mode of larval development. In: McEdward L (ed) Ecology of marine invertebrate larvae. CRC Press, Boca Raton, FL, p 49-78

Killian CE, Metzler RA, Gong Y, Churchill TH, Olson IC, and others (2011) Self-sharpening mechanism of the sea urchin tooth. Adv Funct Mater 21:682-690

Kleypas JA, Feely RA, Fabry VJ, Langdon C, Sabine CL, Robbins LL (2006) Impacts of ocean acidification on coral reefs and other marine calcifiers: a guide for future research, report of a workshop held 18-20 April 2005, St. Petersburg, FL, sponsored by NSF, NOAA and the US Geological Survey.

Koojiman SALM (2010) Dynamic energy and mass budgets in biological systems. Cambridge University Press, Cambridge

> Kroeker KJ, Kordas RL, Crim RN, Singh GG (2010) Metaanalysis reveals negative yet variable effects of ocean acidification on marine organisms. Ecol Lett 13: 1419-1434

Kurihara $\mathrm{H}$ (2008) Effects of $\mathrm{CO}_{2}$-driven ocean acidification on the early developmental stages of invertebrates. Mar Ecol Prog Ser 373:275-284

Kurihara H, Ishimatsu A (2008) Effects of high $\mathrm{CO}_{2}$ seawater on the copepod (Acartia tsuensis) through all life stages and subsequent generations. Mar Pollut Bull 56: 1086-1090

Kurihara H, Shirayama Y (2004) Effects of increased atmospheric $\mathrm{CO}_{2}$ on sea urchin early development. Mar Ecol Prog Ser 274:161-169

Kurihara H, Shimoda S, Shirayama Y (2004) Effects of raised $\mathrm{CO}_{2}$ concentration on the egg production rate and early development of two marine copepods (Acartia steueri and Acartia erythraea). Mar Pollut Bull 49:721-727

> Kurihara H, Matsui M, Furukawa H, Hayashi M, Ishimatsu A (2008) Long-term effects of predicted future seawater $\mathrm{CO}_{2}$ conditions on the survival and growth of the marine shrimp Palaemon pacificus. J Exp Mar Biol Ecol 367: $41-46$

> Kurihara H, Takano Y, Kurokawa D, Akasaka K (2012) Ocean acidification reduces biomineralization-related gene expression in the sea urchin, Hemicentrotus pulcherrimus. Mar Biol 159:2819-2826

Lannig G, Eilers S, Pörtner HO, Sokolova IM, Bock C (2010) Impact of ocean acidification on energy metabolism of oyster, Crassostrea gigas - changes in metabolic pathways and thermal response. Mar Drugs 8: 2318-2339

> Lawrence JM, Olave S, Otaiza R, Lawrence AL, Bustos E (1997) Enhancement of gonad production in the sea urchin Loxechinus albus in Chile fed extruded feed. J World Aquacult Soc 28:91-96

Lewis E, Wallace D (1998) Program developed for $\mathrm{CO}_{2}$ system calculation. http://cdiac.esd.ornl.gov/oceans/ co2rprtnbk.html

Martin S, Richier S, Pedrotti ML, Dupont S and others (2011) 
Early development and molecular plasticity in the Mediterranean sea urchin Paracentrotus lividus exposed to $\mathrm{CO}_{2}$-driven acidification. J Exp Biol 214:1357-1368

Mehrbach C, Culberson CH, Hawley JE, Pytkowicz RM (1973) Measurement of the apparent dissociation constant of carbonic acid in seawater at atmospheric pressure. Limnol Oceanogr 18:897-907

> Melzner F, Gutowaska MA, Langenbuch M, Dupont S, Lucassen M, and others (2009) Physiological basis for high $\mathrm{CO}_{2}$ tolerance in marine ectothermic animals: pre-adaptation through lifestyle and ontogeny? Biogeosciences 6: 2313-2331

> Miles H, Widdicombe S, Spicer JI, Hall-Spencer J (2007) Effects of anthropogenic seawater acidification on acidbase balance in the sea urchin Psammechinus milliaris. Mar Pollut Bull 54:89-96

Morgan SG (1995) The timing of larval release. In: McEdward L (ed) Ecology of marine invertebrate larvae. CRC Press, Boca Raton, FL, p 157-192

> Morgan SG, Christy JH (1994) Plasticity, constraint, and optimality in reproductive timing. Ecology 75:2185-2203

Mucci A (1983) The solubility of calcite and aragonite in seawater at various salinities, tempeartures, and one atmosphere total pressure. Am J Sci 283:780-799

O'Donnell MJ, Todgham AE, Sewell MA, Hammond LM and others (2010) Ocean acidification alters skeletogenesis and gene expression in larval sea urchins. Mar Ecol Prog Ser 398:157-171

Orr JC, Fabry VJ, Aumont O, Bopp L, Doney SC, and others (2005) Anthropogenic ocean acidification over the twenty-first century and its impact on calcifying organisms. Nature 437:681-686

R Development Core Team (2011). R: A language and environment for statistical computing. R Foundation for Statistical Computing, Vienna

> Reuter KE, Lotterhos KE, Crim RN, Thompson CA, Harley CDG (2011) Elevated $\mathrm{pCO}_{2}$ increases sperm limitation and risk of polyspermy in the red sea urchin Strongylocentrotus franciscanus. Glob Change Biol 17:163-171

Riebesell U, Zondervan I, Rost B, Tortell PD, Zeebe RE, Morel FMM (2000) Reduced calcification of marine plankton in response to increased atmospheric $\mathrm{CO}_{2}$. Nature 407:364-367

Ries JB, Cohen AL, McCorkle DC (2009) Marine calcifiers exhibit mixed responses to $\mathrm{CO}_{2}$-induced ocean acidification. Geology 37:1131-1134

Schneider JE (2004) Energy balance and reproduction. Physiol Behav 81:289-317

Sheppard Brennand H, Soars N, Dworjan SA, Davis AR, Byrne M (2010) Impact of ocean warming and ocean acidification on larval development and calcification in the sea urchin Tripneustes gratilla. PLoS ONE 5:e11372

> Shirayama Y, Thornton H (2005) Effect of increased atmospheric $\mathrm{CO}_{2}$ on shallow water marine benthos. J Geophys Res 110, doi:10.1029/2004JC002618

Sibly RM, Calow P (1986) Physiology ecology of animals. An evolutionary approach. Blackwell Scientific Publications, Palo Alto, CA

Siikavuopio SI, Mortensen A, Dale T, Foss A (2007) Effects of carbon dioxide exposure on feed intake and gonad growth in green sea urchin, Strongylocentrotus droebachiensis. Aquaculture 266:97-101

Sokolova IM, Federich M, Bagwe R, Lannig G, Sukhotin AA (2012) Energy homeostasis as an integrative tool for assessing limits of environmental stress tolerance in aquatic invertebrates. Mar Environ Res 79:1-15

Spicer JI, Widdicombe S, Needham HR, Berge JA (2011) Impact of $\mathrm{CO}_{2}$-acidified seawater on the extracellular acid-base balance of the northern sea urchin Strongylocentrotus drobachiensis. J Exp Mar Biol Ecol 407: $19-25$

> Stumpp M, Wren J, Melzner F, Throndyke MC, Dupont ST (2011a) $\mathrm{CO}_{2}$ induced seawater acidification impacts sea urchin larval development I: Elevated metabolic rates decrease scope for growth and induce developmental delay. Comp Biochem Physiol 160A:331-340

> Stumpp M, Dupont S, Throndyke MC, Melzner F (2011b) $\mathrm{CO}_{2}$ induced seawater acidification impacts sea urchin larval development II: Gene expression patterns in pluteus larvae. Comp Biochem Physiol 160A:320-330

Stumpp M, Trübenbach K, Brennecke D, Hu MY, Melzner F (2012) Resource allocation and extracellular acid-base status in the sea urchin Strongylocentrotus drobachiensis in response to $\mathrm{CO}_{2}$ induced seawater acidification. Aquat Toxicol 110-111:194-207

Sunday JM, Crim RN, Harley CDG, Hart MW (2011) Quantifying rates of evolutionary adaptation responses to ocean acidification. PLoS ONE 6:e22881

Thompson RJ (1983) The relationship between food ration and reproductive effort in the green sea urchins, Strongylocentrotus drobachiensis. Oecologia 56:50-57

Todgham AE, Hofmann GE (2009) Transcriptome response of sea urchin larvae Strongylocentrotus purpuratus to $\mathrm{CO}_{2}$-driven seawater acidification. J Exp Biol 212: 2579-2594

Unuma T, Yamamoto T, Akiyama T, Shiraishi M, Ohta H (2003) Quantitative changes in yolk protein and other components in the ovary and testis of the sea urchin Pseudocentrotus depressus. J Exp Biol 206:365-372

> Walker CW, Lesser MP (1998) Manipulation of food and photoperiod promotes out-of-season gametogenesis in the green sea urchin, Strongylocentrotus drobachiensis: implications for aquaculture. Mar Biol 132:663-676

Walker CW, McGinn NA, Harrington LM, Lesser MP (1998) New perspectives on sea urchin gametogenesis and their relevance to aquaculture. J Shellfish Res 17:1507-1514

> Walker CW, Harrington LM, Lesser MP, Fagerberg WR (2005) Nutrient phagocyte incubation chambers provide a structural and nutritive microenvironment for germ cells of Strongylocentrotus droebachiensis, the green sea urchin. Biol Bull 209:31-48

Walker CW, Unuma T, Lesser MP (2007) Gametogenesis and reproduction of sea urchins. In: Lawrence JM (ed) Edible sea urchins: biology and ecology. Elsevier, Amsterdam, p 11-28

Wood HL, Spicer JL, Widdicombe S (2008) Ocean acidification may increase calcification rates, but at a cost. Proc R Soc Lond B Biol Sci 275:1767-1773

Yamamoto M, Ishine M, Yoshida M (1988) Gonadal maturation independent of photic conditions in laboratoryreared sea urchin Pseudocentrotus depressus and Hemicentrotus pulcherrimus. Zool Sci 5:979-988

> Yu PC, Matson PG, Martz TR, Hofmann GE (2011) The ocean acidification seascape and its relationship to the performance of calcifying marine invertebrates: laboratory experiments on the development of sea urchin larvae framed by environmentally-relevant $\mathrm{pCO}_{2} / \mathrm{pH}$. J Exp Mar Biol Ecol 400:288-295

Zera A, Harshman LG (2001) The physiology of life history trade-offs in animals. Annu Rev Ecol Syst 32:95-126 